\title{
GABA signaling: A route to new pancreatic $\beta$ cells
}

\author{
Cell Research (2017) 27:309-310. doi:10.1038/cr.2017.20; published online 10 February 2017
}

\begin{abstract}
An ability to convert between pancreatic islet cell types may provide a new approach to replace insulinsecreting $\beta$ cells destroyed by autoimmune attack in Type 1 diabetes. Two papers, which have recently appeared in Cell, describe how this might be achieved.
\end{abstract}

Diabetes mellitus (DM) affects > 400 million individuals worldwide and new treatments are desperately needed to treat this growing epidemic. Pancreatic $\beta$ cells, located within the islet micro-organ, are the sole source of secreted insulin in mammals [1]. Autoimmunity-induced destruction of $\beta$ cells is the underlying cause of Type $1 \mathrm{DM}$, whereas more subtle decreases in cell mass and functional impairment drive Type 2 DM [1]. Strategies to replace destroyed $\beta$ cells in T1 DM are currently hindered by the absence of sufficient transplantable material, usually obtained post-mortem from donors. New approaches, conceivably involving the regeneration of $\beta$ cells in vivo, are therefore urgently sought.

Pancreatic $\beta$ cells are co-located within the islet alongside other hormone-secreting cells, including glucagon-secreting $\alpha$ cells, somatostatinsecreting $\delta$ cells and others. Although enhanced $\beta$ cell proliferation has been considered a possible approach to treating $\mathrm{T} 1 \mathrm{DM}$, the near complete loss of $\beta$ cells in this disease means that neogenesis from an alternate cellular pool may be more realistic, especially given mounting evidence for islet cell plasticity [2]. Towards this end, earlier studies by Herrera and coworkers [3], and Collombat and colleagues [4], demonstrated the possibility of converting $\alpha$ to $\beta$ cells in vivo. This occurred in response to the destruction of $\beta$ cells, or after modifying the expression of critical transcription factors, respectively. However, a means of achieving such a fate switch in a controlled and therapeutically tractable manner has so far proved elusive.

Firstly, Li et al. [5] established an assay for Arx function, a transcription factor required to maintain $\alpha$ cell phenotype. Overexpression of this factor in the clonal $\beta$ cell line MIN6 provided the basis of a screen for small molecules which inhibited Arx, consequently increasing insulin gene expression. In this way, the authors identified artemisinins, including the antimalarial drug artemether, as effective regulators of Arx function and cell identity. A further chemical proteomics screen then identified gephyrin as the likely receptor for artemether. Gephyrin is a key regulator of $\gamma$-aminobutyric acid (GABA) synthesis and $\mathrm{GABA}_{\mathrm{A}}$ receptor trafficking. Strikingly, artemether increased $\beta$ cell numbers in vivo in both mice and zebrafish, and lineage tracing analysis showed that this was due to $\alpha$ to $\beta$ cell conversion [5]. Artemether-treated clonal $\alpha$ cells ( $\alpha \mathrm{TC} 1-6)$ also displayed Arx exclusion from the nucleus and altered depolarization-induced $\mathrm{Ca}^{2+}$ dynamics [5], consistent with enhanced GABA receptor expression. Importantly, single cell RNA-seq experiments demonstrated similar effects in human $\alpha$ cells.

Complementing the above study, Ben-Othman and co-workers [6] performed a transcriptional screen to identify genes upregulated by overexpression of Pax 4 in $\alpha$ cells, a manoeuvre which favors $\alpha$ to $\beta$ cell switching [6].
Many of the most strongly upregulated genes were involved in GABA signaling. Correspondingly, treatment of aTC1-6 cells with GABA decreased the expression of Arx, suggesting that the neurotransmitter favors the conversion of $\alpha$ to $\beta$ cells in vivo. Providing a direct demonstration of this hypothesis, treatment of mice for 2-6 months led to a remarkable ( $>3$-fold) increase in $\beta$ cell mass. Again, lineage tracing using a glucagon promoter-driven Cre to drive $\beta$-gal expression revealed that the vast majority of the "additional" $\beta$ cells were derived from a glucagon-positive progenitor.

Extending this work to a model of T1 DM, these authors [6] went on to show that the effects of $\beta$ cell destruction with the chemical agent streptozotocin were reversed by GABA and that this resulted from the generation of $\beta$ from $\alpha$ cells.

There are, nonetheless, several intriguing aspects of these studies which will require further investigations. Firstly, within the intact healthy islet, GABA is chiefly released from $\beta$ cells and, at least in the case of rodent islets where blood flow is known to be in the direction of $\beta$ to $\alpha$ cells [7], is likely then to act on $\alpha$ cells. According to the new findings, GABA action should consequently favor conversion of $\alpha$ to $\beta$ cells. The loss of this input therefore seems unlikely to explain $\alpha$ to $\beta$ cell conversion after the artificial destruction of $\beta$ cells in mice [3] and would be expected to hinder $\beta$ cell neogenesis after this destruction of these cells in T1 DM.

Secondly, what signaling mechanisms within $\alpha$ cells are responsible for the observed changes in Arx expression, and ultimately the switch to a $\beta$ cell phe- 


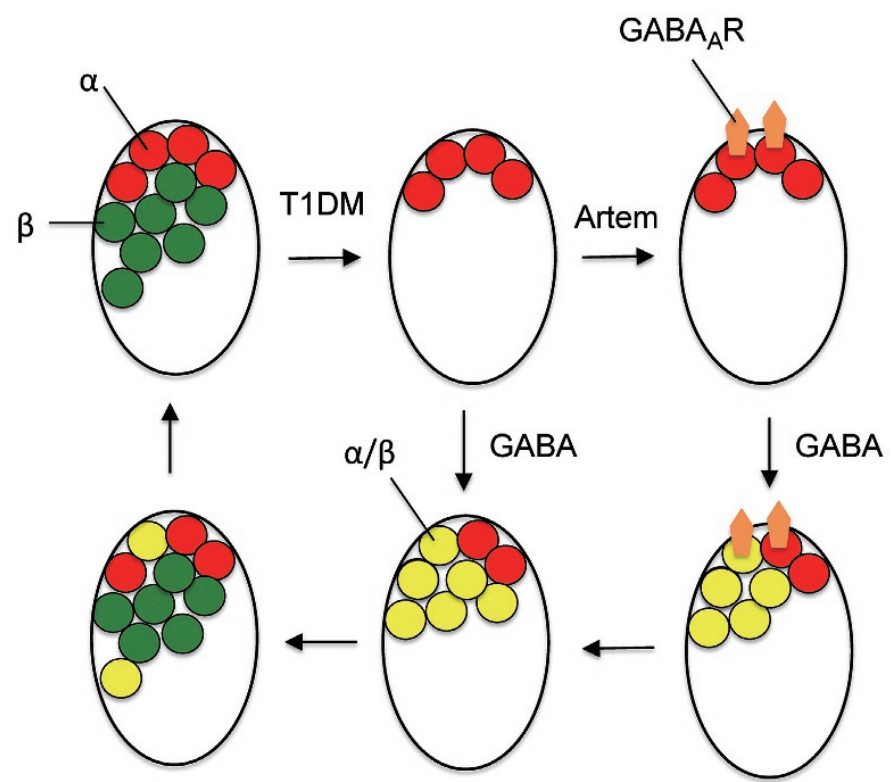

Figure 1 Mechanisms through which GABA receptor agonists or artemisinins may be used to provoke an $\alpha$ to $\beta$ cell fate switch to correct the destruction of $\beta$ cells in T1 DM. Clockwise from top left: $\beta$ cells (green) are destroyed in T1 DM, leaving a cells (red) largely unaffected. Artemisinins prompt the upregulation of $\mathrm{GABA}_{A}$ receptors (orange), favoring the actions of GABA to prompt the conversion of a proportion of $\alpha$ cells to an intermediate phenotype (yellow). Further proliferation and redifferentiation replenishes the depleted $\beta$ cell pool, restoring normal glycemia.

notype? Whilst increased $\mathrm{Ca}^{2+}$ can elicit dramatic changes in cellular phenotype, for example after oocyte fertilization [8], how a decrease in $\mathrm{Ca}^{2+}$, as provoked by artemether or $\mathrm{GABA}_{\mathrm{A}}$ receptor activation (prompting an influx of $\mathrm{Cl}^{-}$ions) [5], could alter gene expression in the $\alpha$ cell in such a dramatic manner remains to be established. Identification of the molecular machinery linking GABAinduced changes in $\mathrm{Ca}^{2+}$ to altered Arx localization and expression represents an important new challenge.

What is the immediate translational potential of these results? $\mathrm{GABA}_{\mathrm{A}}$ receptor agonists are in current clinical use as a treatment for epilepsy [9] whilst artemether is widely deployed as an antimalarial drug [10]. Both are therefore considered safe for use in humans. Clinical trials with these agents should therefore be feasible and should reveal whether GABA treatment might provide the basis of exciting new regenerative treatments for T1 DM (Figure 1).

\section{Guy A Rutter ${ }^{1}$}

${ }^{1}$ Cell Biology and Functional Genomics, Division of Diabetes, Endocrinology and Metabolism, Imperial College London, Du Cane Road, London, W12 0NN, UK

Correspondence: Guy A Rutter

E-mail: G.rutter@imperial.ac.uk

\section{References}

1 Rutter GA, Pullen TJ, Hodson DJ, et al. Biochem J 2015; 466:202-218.

2 Bramswig NC, Everett LJ, Schug J, et al. J Clin Invest 2013; 123:1275-1284.

3 Thorel F, Nepote V, Avril I, et al. Nature 2010; 464:1149-1154.

4 Collombat P, Xu X, Ravassard P, et al. Cell 2009; 138:449-462.

5 Li J, Casteels T, Frogne T, et al. Cell 2017; 168:86-100.

6 Ben-Othman N, Vieira A, Courtney M, et al. Cell 2017; 168:73-85.

7 Samols E, Stagner JI, Ewart RB, et al. J Clin Invest 1988; 82:350-353.

8 Gonzalez-Garcia JR, Machaty Z, Lai FA, et al. J Cell Physiol 2013; 228:110-119.

9 Gambardella A, Labate A, Cifelli P, et al. Pharmacol Res 2016; 113(Pt A):421-425.

10 Dondorp AM, Fanello CI, Hendriksen IC, et al. Lancet 2010; 376:1647-1657. 